\title{
QUANTITATIVE ANALYSIS OF CARDIAC LESIONS IN CHRONIC CANINE CHAGASIC CARDIOMYOPATHY
}

Marcelo Vidigal CALIARI(1), Raquel do Pilar MACHADO(4), Marta de LANA(3), Rosângela Aparecida França CAJÁ(1), Cláudia Martins CARNEIRO(3), Maria Teresinha BAHIA(4), César Augusto Bueno dos SANTOS(5), Gustavo Albergaria MAGALHÃES(1), Ivan Barbosa Machado SAMPAIO(2) \& Washington Luiz TAFURI(1)

\begin{abstract}
SUMMARY
Lesions observed in chronic chagasic cardiopathy frequently produce electrocardiographic alterations and affect cardiac function. Through a computerized morphometrical analysis we quantified the areas occupied by cardiac muscle, connective and adipose tissues in the right atrium of dogs experimentally infected with Trypanosoma cruzi. All of the infected dogs showed chronic myocarditis with variable reduction levels of cardiac muscle, fibrosis and adipose tissue replacement. In the atrial myocardium of dogs infected with Be78 and Be62 cardiac muscle represented 34 and 50\%, fibrosis 28 and $32 \%$ and adipose tissue 38 and $18 \%$, respectively. The fibrosis observed was both diffuse and focal and mostly intrafascicular, either partially or completely interrupting the path of muscle bundles. Such histological alterations probably contributed to the appearance of electrocardiographic disturbances verified in 10 out 11 dogs which are also common in human chronic chagasic cardiopathy. Fibrosis was the most important microscopic occurrence found since it produces rearrangements of collagen fibers in relation to myocardiocytes which causes changes in anatomical physiognomy and mechanical behavior of the myocardium. These abnormalities can contribute to the appearance of cardiac malfunction, arrythmias and congestive cardiac insufficiency as observed in two of the analyzed dogs. Strain Be78 caused destruction of atrial cardiac muscle higher than that induced by strain Be62.
\end{abstract}

KEYWORDS: Trypanosoma cruzi; Chagasic cardiomyopathy; Myocarditis; Fibrosis; Congestive cardiac insufficiency.

\section{INTRODUCTION}

Chagas disease (American trypanosomiasis) is caused by the flagellate protozoa Trypanosoma cruzi, occurs in almost all of Latin America's countries and is thus a serious public health problem ${ }^{13}$.

The chagasic infection is characterized by an acute phase, either symptomatic or not, approximately two months-long, evolving to a chronic phase that persists for the rest of the host's life. Five to twenty years after the beginning of the infection, about 20 to $30 \%$ of the patients exhibit fibrosing cardiopathy (decompensate or not), which is the greatest cause of morbidity and mortality in the chronic phase of the disease ${ }^{31}$.

Up to now, pathogenesis of the chronic phase is not fully understood, especially by the difficulty in finding the parasite and by the lack of correlation between parasitism and the inflammatory process. According to the vast literature on the subject ${ }^{28}$, many factors have been suggested to explain the pathogenesis and the development of chagasic cardiopathy. Among the various factors mentioned, such as direct destruction of the muscular tissue by $T$. cruzi, lesions of the intracardiac nervous system, microangiopathy and autoimmunity, fibrosis is maybe one of the most important factors.
The myocardiac extracellular matrix is predominantly constituted by collagen I and III which sustain the myocardiocytes, maintaining their alignment, interfering with tension levels, elasticity and muscular rigidity and also keeping the shape and thickness of the muscular bundles ${ }^{32}$. The cardiac function is affected not only by the area of the myocardium occupied by collagen, but also by the structural characteristics and arrangement of the collagen fibers in respect to the myocardiocytes. Progressive myocardiac fibrosis produces rearrangements in collagen fibers, modifying the anatomical aspect of the organ and influencing on the mechanical behavior of the myocardium.

The genesis and distribution of inflammation explain the type of fibrosis that progressively develops from the beginning of chagasic infection. Only chronic chagasic cardiopathy myocarditis shows such intense fibrosis and peculiar characteristics ${ }^{7}$. The installed fibrosis is, at the same time, diffuse and focal and is mostly intrafascicular. This fibrosis arises in the endomysium as a replacement fibrosis of lost cardiomyocytes and as cicatricial fibrosis of inflammatory foci in resolution. An increase in number and thickness of tendon-like structures and collagen strands is observed in the perimysium together with a diffuse increase in thickness of the endomysial collagen, mainly those fibers adjacent to perimysium ${ }^{25}$. Both the diffuse and focal fibrosis interrupt partially or totally the path

(1) Departamento de Patologia Geral, ICB, Universidade Federal de Minas Gerais, 31270-901 Belo Horizonte, MG, Brasil.

(2) Departamento de Zootecnia, Escola de Veterinária, Universidade Federal de Minas Gerais, 31270-901 Belo Horizonte, MG, Brasil.

(3) Departamento de Análises Clínicas, Escola de Farmácia, Universidade Federal de Ouro Preto, 35400-000 Ouro Preto, MG, Brasil.

(4) Departamento de Ciências Biológicas, ICEB, Universidade Federal de Ouro Preto, 35400-000 Ouro Preto, MG, Brasil.

(5) Departamento de Ciências Biológicas, Universidade do Vale do Rio Doce, 35020-220 Governador Valadares, MG, Brasil.

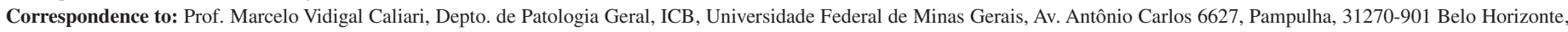
MG, Brasil.. Tel: +55-31-3499-2892; Fax: +55-31-3499-2879; Email: caliari@icb.ufmg.br 


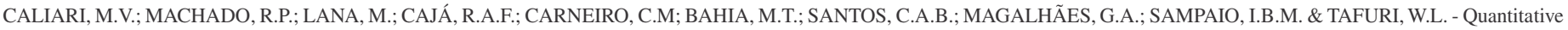
analysis of cardiac lesions in chronic canine chagasic cardiomyopathy. Rev. Inst. Med. trop. S. Paulo, 44(5):273-278, 2002.

of muscular bundles, reach the perimysium and join adjacent fascicles to each other. Therefore, decompensate chronic fibrousing cardiopathy showing serious rhythm disturbances is due to these multi focal and diffuse fibrosis that develop along time ${ }^{22}$.

From the anatomopathological point of view the most important fact of this model is that it reproduces the fibrosing chronic chagasic cardiopathy in a manner very similar to that observed in humans. Since it is hard to reproduce that condition in other experimental models, our group has been developing this line of research since $1982^{10,19,20,30}$. According to our experience, the inflammatory process installed in the myocardium of the dog occurs in systematized and/or diffuse foci, reaching systematically the whole heart, and specially the atria. We have decided to study only the right atrium, since everything that could be occurring in other areas of the myocardium was represented in it. Since, up to this moment, there are no data in the literature about the distribution of fibrosis in the chronic chagasic dog and in the connective tissue of the control dogs, this work aims to perform a morphometrical study about the areas occupied by cardiac muscle, connective and adipose tissues in the atrium of dogs chronically infected by Trypanosoma cruzi and in normal dogs. Such data will constitute the basis for future studies about modulation of collagen due to imbalance of the immune response.

\section{MATERIAL AND METHODS}

Dogs and infection: Seventeen young mongrel dogs (65-70 daysold) were used in the experiment. Dogs were born and maintained in animal facilities under controlled experimental conditions: they were all
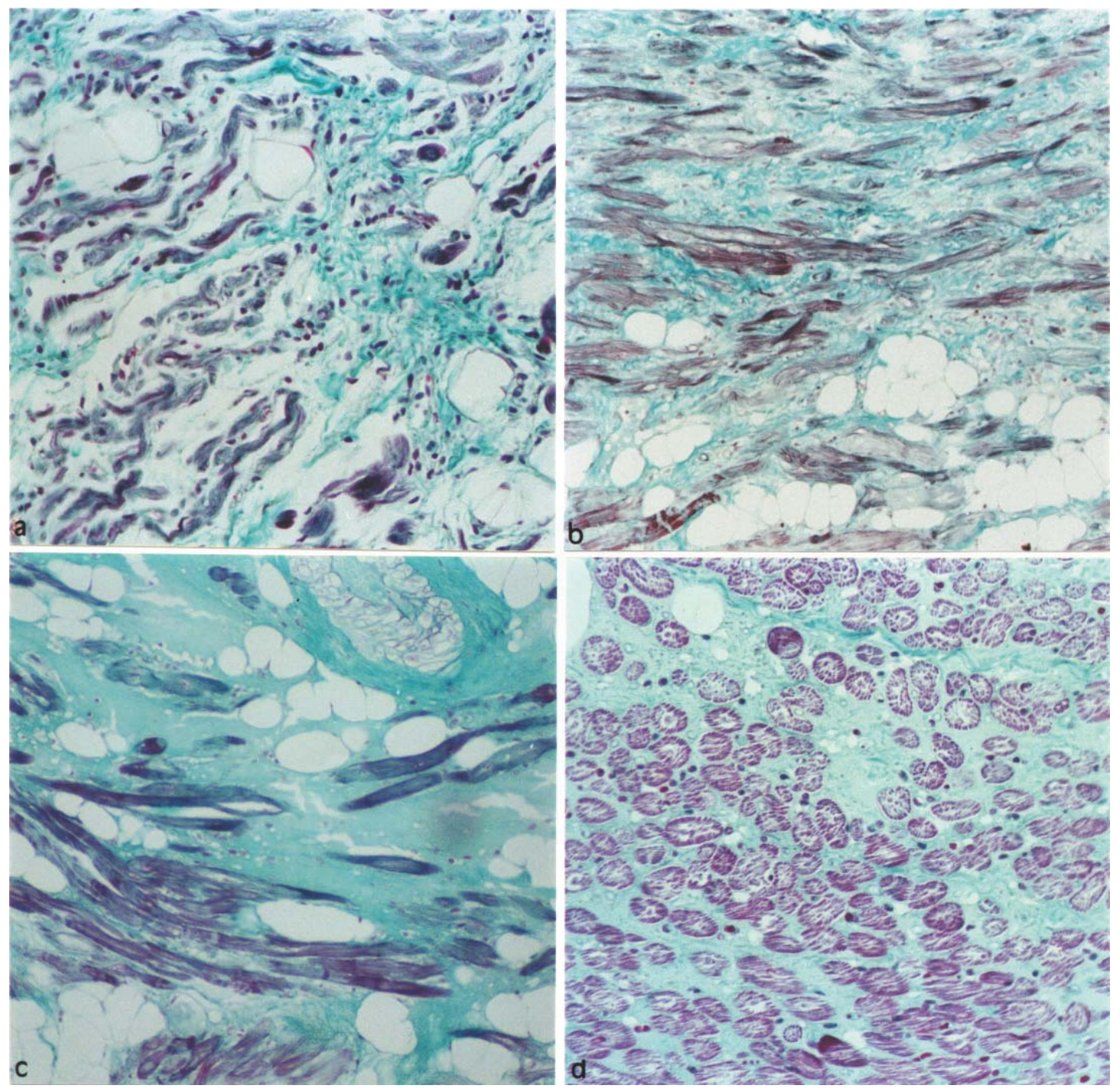

Fig. 1 - Atrial myocardium of dogs inoculated with T. cruzi and necropsied in the chronic phase of Chagas disease. (a) Chronic diffuse fibrosing myocarditis with mononuclear exsudation and discreet predominantly perimisial fibrosis ( $\operatorname{dog} 2$ ) (Magnification: x120). (b) Chronic fibrosing myocarditis showing accentuated perimysial and endomysial collagen neoformation, separating and dissecting degenerated and/or hypertrophied myocardiocyte bundles. Presence of adipose tissue (dog 9) (Magnification: x120). (c) Intense diffuse fibrosis, also around the coronary epicardiac branch, involving degenerated myocardiocytes. Presence of adipose tissue (dog 5) (Magnification: x230). (d) Sagittal sectioning of myocardiocytes, showing their morphologically normal aspect and partial enclosing by thick endomysial extracellular matrix. Discreet mononuclear infiltrate (dog 4) (Magnification: x230). Gomori's trichrome stain. 


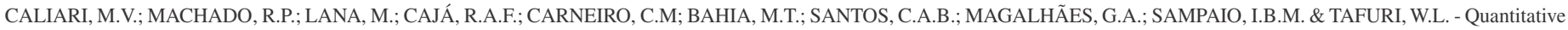
analysis of cardiac lesions in chronic canine chagasic cardiomyopathy. Rev. Inst. Med. trop. S. Paulo, 44(5):273-278, 2002.

negative for anti-T. cruzi antibodies, had normal hemogram and electrocardiogram (ECG).

Six animals were inoculated by the conjunctival route with 2,000 metacyclic trypomastigotes/Kg of $T$. cruzi Berenice 78 strain (Be78) and five dogs were inoculated in the same way with the Berenice 62 strain $(\mathrm{Be} 62)^{18}$ and were submitted to necropsy in the chronic phase. These strains were isolated from patient Berenice which is considered the first human clinical case of Chagas disease ${ }^{12}$. Metacyclic trypomastigotes were obtained from previously infected nymphs of Dipetalogaster maximus. Counting of trypomastigotes was performed according to $\mathrm{BRENER}^{8}$ and adjustment of inoculum was done with sterile buffered saline solution. Infection of the dogs was confirmed through examination of fresh blood. The six remaining animals constituted the control group.

Necropsy: All animals were euthanased by a thionembutal injection (Abbott, São Paulo, Brazil). The eleven chronic infected dogs were sacrificed between approximately 22 and 129 months after infection. Necropsy was performed and a fragment of approximately $1.0 \times 1.0 \times$ $0.2 \mathrm{~cm}$ from the middle of the right atrial wall of each dog was taken for histopathological processing. The six control dogs were sacrificed by the same age as the experimental animals.

Histopathology: Fragments were fixed in 10\% buffered formalin solution, dehydrated, cleared and embedded in paraffin. Blocks were cut into $4 \mu \mathrm{m}$-thick sections stained by hematoxylin and eosin (H\&E) for routine histopathological exam and Gomori's trichrome for the quantitative study.

Morphometric analyses: Fifteen images were randomly chosen at 10X from each Gomori's trichrome section (performing a total of $1,3070880 \times 10^{7} \mu \mathrm{m}^{2}$ analyzed myocardium). Images were obtained through a JVC TK-1270/RGB microcamera and the KS300 software built in a Kontron Elektronick/Carl Zeiss image analyzer ${ }^{9}$. Using the image segmentation function, all pixels with green hues were selected for creation of a binary image and subsequent calculation of the total area occupied by connective tissue in the chagasic dogs. The same procedure was adopted for calculation of the area occupied by cardiac muscle and adipose tissue, through selection of the red and white pixels, respectively. All of the areas obtained were compared through the Student's $t$-test (GraphPad InStat software) between control dogs and those infected by both strains.

\section{RESULTS}

Necropsy and Histopathology: Two out of the eleven animals infected with $T$. cruzi exhibited cardiomegaly: heart had a globous shape, tip was formed by the two ventricles and cardiac chambers were dilated, specially the right atrium; hydropericardium was also observed in six dogs (Table 1). Chronic fibrosing chagasic myocarditis was detected under light microscopy in all animals (Fig. 1a); focal and diffuse myocarditis were discreet to moderate and showed to be constituted by a mononuclear infiltrate. This infiltrate showed endomysial distribution mainly between normal myocardiocytes but also around damaged cells. The deposition of perimysial and endomysial extracellular matrix occurred at varying degrees, and was mostly diffuse, sometimes associated with the inflammatory infiltrate. Such fibrosis causes disorganization and isolation
Table 1

Period of infection and macroscopic findings of dogs inoculated with Trypanosoma cruzi strain Be62 and Be78

\begin{tabular}{lccl}
\hline Dog & $\begin{array}{c}\text { Period of } \\
\text { infection } \\
\text { (months) }\end{array}$ & T. cruzi strain & \multicolumn{1}{c}{ Macroscopy } \\
\hline 1 & 29 & Be78 & Normal \\
2 & 22 & Be78 & Hydropericardium \\
3 & 22 & Be78 & Hydropericardium \\
4 & 111 & Be78 & Cardiomegaly \\
5 & 124 & Be78 & Hydropericardium \\
6 & 129 & Be78 & Hydropericardium \\
7 & 56 & Be62 & Normal \\
8 & 116 & Be62 & Hydropericardium \\
9 & 116 & Be62 & Cardiomegaly \\
10 & 72 & & Hydropericardium \\
11 & 72 & Be62 & Normal \\
\hline
\end{tabular}

of normal, degenerated and/or hypertrophic myocardiocytes (Figs. 1b, c). Collagen fibers were thicker than usual, especially in the perimysium. The endomysium was also thicker, especially in areas that did not show significant destruction of myocardiocytes (Fig. 1d). Amastigote nests were not observed. Myocardium of the six control dogs was histologically normal with rare mononuclear cells.

Morphometric results: In the atrial myocardium of control dogs a mean area of 10,010,797 $\pm 1,173,943 \mu \mathrm{m}^{2}(82 \%), 925,135 \pm 260,647.7$ $\mu \mathrm{m}^{2}(8 \%)$ and $1,194,527 \pm 348,611.9 \mu \mathrm{m}^{2}(10 \%)$ was observed, respectively, for cardiac muscle, connective and adipose tissues. A significant increase in connective and adipose tissues, accompanied by reduction of area occupied by cardiac muscle was observed in the animals inoculated with strain Be78. In these animals the area occupied by cardiac muscle, connective and adipose tissue was on average 4,329,250 \pm $798,490 \mu \mathrm{m}^{2}$ (34\%), 3,565,280 $\pm 1,221,871 \mu \mathrm{m}^{2}(28 \%)$ and 4,977,267 \pm $598,094.9 \mu \mathrm{m}^{2}(38 \%)$, respectively. However in dogs inoculated with the strain Be62, reduction in the area occupied by cardiac muscle was smaller $\left(5,906,050 \pm 675,075.1 \mu \mathrm{m}^{2}-50 \%\right)$ than that produced by strain Be78. Despite this difference, the area occupied by connective tissue $\left(3,880,309 \pm 905,989.3 \mu \mathrm{m}^{2}-32 \%\right)$ was close to that observed in dogs inoculated with Be78, while there was a reduction in the area occupied by adipose tissue $\left(2,186,441 \pm 614,570.2 \mu \mathrm{m}^{2}-18 \%\right)$. Figures 2,3 and 4 show the absolute morphometrical data of all dogs. Statistical results are shown in Table 2.

\section{DISCUSSION}

Structural abnormalities lead to cardiac dysfunction contributing to the appearance of arrhythmias and development of $\mathrm{CCI}^{27}$. Accumulation of collagen fibers in hypertensive cardiopathy is a fundamental factor in the dysfunction of the cardiac pump; it can progressively lead to an alteration of the ventricular function, initially during the diastole and, 


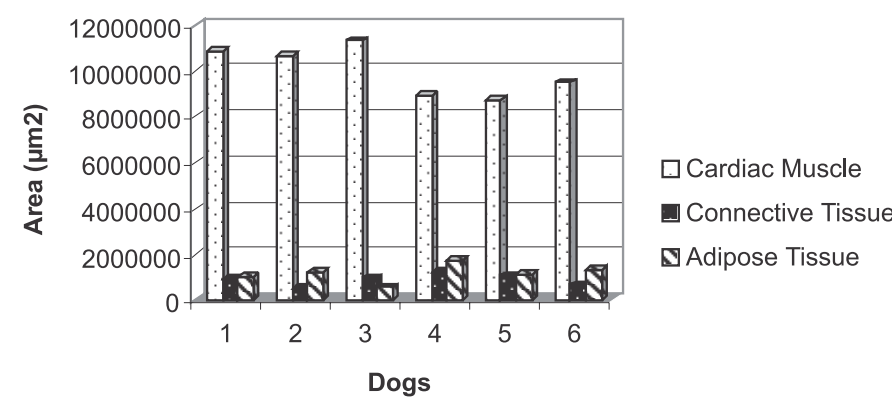

Fig. 2 - Area occupied by cardiac muscle, connective and adipose tissues in control dogs.

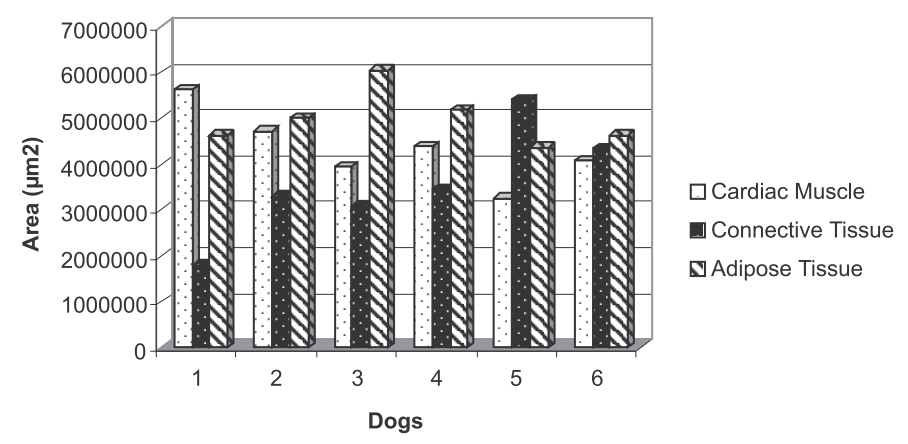

Fig. 3 - Area occupied by cardiac muscle, connective and adipose tissues in dogs inoculated with strain Be78.

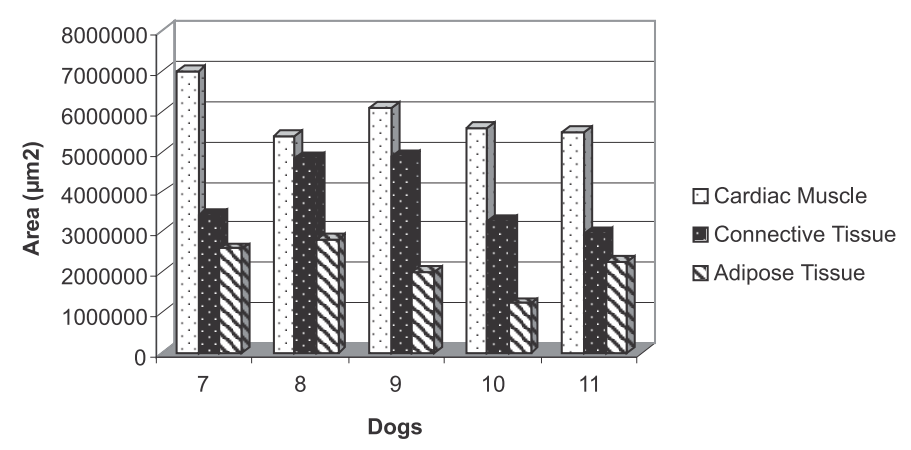

Fig. 4 - Area occupied by cardiac muscle, connective and adipose tissues in dogs inoculated with strain Be62.

afterwards during the systole ${ }^{33}$. Similarly to what happens in human hypertensive cardiopathy it was verified experimentally a diffuse increase in the amount of endomysial collagen, associated to an increase in heart weight ${ }^{26}$. It has also been observed in this same model a disorganized increase in the perimisial extracellular matrix and dense scattered scarlike foci, probably to replace myocytolysis. It is possible that fibrogenic factors that are significantly increased in hypertension, such as the reninangiotensin-aldosterone system, could be involved in myocardial fibrosis observed in hypertensive cardiopathy ${ }^{34}$.

In chronic human chagasic cardiopathy fibrosis is diffuse and shows variable degree of collagen deposition, reaching the perimysium,
Table 2

Statistical analyses of areas of cardiac muscle, connective and adipose tissues in the right atrium of control and infected dogs

\begin{tabular}{lll}
\hline Areas & Groups & Statistical results \\
\hline Cardiac Muscle & $*$ Be78 x Be62 & $\mathrm{t}=3.49 ; \mathrm{p}=0.0068$ \\
& $* *$ Controls x Infecteds & $\mathrm{t}=9.02 ; \mathrm{p}<0.0001$ \\
Connective Tissue & $*$ Be78 x Be62 & $\mathrm{t}=0.47 ; \mathrm{p}=0.64$ \\
& $* *$ Controls x Infecteds & $\mathrm{t}=6.3 ; \mathrm{p}<0.0001$ \\
Adipose Tissue & $*$ Be78 x Be62 & $\mathrm{t}=7.61 ; \mathrm{p}<0.0001$ \\
& $* *$ Controls x Infecteds & $\mathrm{t}=3.81 ; \mathrm{p}=0.0017$ \\
\hline
\end{tabular}

* Comparison between areas obtained in animals inoculated with strains Be78 and Be62. ** Comparison between areas obtained in control and infected dogs.

endomysium and can also be observed around intramyocardiac coronary vases $^{7,23}$. Foci with intense collagen deposition related to degeneration and necrosis of myocardiocytes and chronic inflammatory infiltrate are also found ${ }^{25}$. This myocardial destruction and focal and diffuse fibrosis, which are not directly associated with parasitism, indicates a progressive chronic inflammation probably correlated with immunological mechanisms $s^{1,28,29}$. The same morphologic findings occurred in dogs chronically infected with $T$. cruzi. Chagasic dogs exhibited a significant reduction of the cardiac muscle and an increase of the area occupied by connective tissue, when compared to normal dogs. A previous analysis of the myocardium of these dogs indicated the absence of parasites or vascular lesions ${ }^{10}$, suggesting the involvement of other mechanisms in the genesis of chronic canine chagasic myocarditis.

The degree of cardiac hypertrophy, fibrosis and inflammatory infiltrate is a determining factor in the development of CCI and rhythm alterations in chagasic cardiopathy ${ }^{7}$. Hypertrophy, degeneration and fibrosis are more intense in patients with electrocardiographic alterations, with or without $\mathrm{CCI}^{5,22}$. In our study two dogs developed CCI and fibrosis occupied a great percentage of the area in one of them. Counting of $\mathrm{CD}^{+} \mathrm{T}$ cells from these same dogs, performed previously ${ }^{10}$, showed that the largest number of lymphocytes was observed in the dog that exhibited cardiomegaly and intense fibrosis. However, such correlation was not observed in the other dog which also presented CCI. In this case, other factors such as lesions of the autonomous innervation and conduction tissue could be involved. Correlation between intensity of inflammatory infiltrate and fibrosis was not observed in any of the other animals. However, these histological alterations were present in $100 \%$ of the cases and were accompanied by electrocardiographic alterations in most of the cases.

The left ventricle and the right atrium are the regions mostly affected by chagasic myocarditis ${ }^{25}$. The extent of lesions in other chambers cannot be extrapolated based on studies of the right atrial wall. However, lesions in Chagas disease appear so diffuse that the effect of fibrosis on the cardiac function can be analyzed as a whole ${ }^{22}$.

Electrocardiographic alterations observed in chagasic cardiopathy indicate some degree of histological abnormality ${ }^{3,5}$. In most of the studied dogs ECG abnormalities were observed ${ }^{4,19}$. Although there is not a pattern for a electrocardiogram of human chagasic cardiopathy, some alterations 


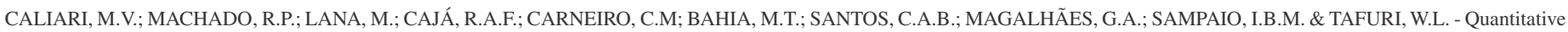
analysis of cardiac lesions in chronic canine chagasic cardiomyopathy. Rev. Inst. Med. trop. S. Paulo, 44(5):273-278, 2002.

in the chronic phase have been observed with higher frequency by various researchers ${ }^{4,15,17,21}$. Basically they involve disturbance of the intraventricular and AV nodule conductions, arrhythmias, ST segment and $\mathrm{T}$ wave alterations. These findings are corroborated in most of dogs studied in this work (10 out of 11) in which the main alterations were: low voltage QRS complexes (present only in dogs infected with Be-78), ventricular repolarization disturbances, ST segment elevation, unifocal ventricular premature complexes and right bundle branch block (RBBB) associated to left anterior fascicular block (LAFB) (unpublished data).

LANA et al. ${ }^{19}$ showed that strain Be-78 is more pathogenic than Be62 in the chronic phase of the disease. This explains the fact that dogs infected with strain Be-78 exhibit more electrocardiographic alterations than those infected with Be-62. Thus, it seems that there is a narrow correlation between the electrocardiographic findings in infected dogs and chagasic humans.

It is also noteworthy the highest reduction of cardiac muscle in the dogs inoculated with strain Be78. The in situ immunophenotypic analysis performed on the right atrial wall of the dogs demonstrated that those inoculated with strain Be78 exhibited a CD4:CD8 ratio equals to 0.88, while this ratio changed to 2.01 in those inoculated with strain Be62 $2^{10}$. Such differences were also detected in circulating blood and spleen ${ }^{11}$. The presence of a larger number of $\mathrm{CD}^{+} \mathrm{T}$ cells in the dogs inoculated with Be78 suggests an important role for such cells in the genesis of lesions.

A significant replacement of the destroyed myocardium by adipose tissue was also verified which had also been described by others ${ }^{2}$. In all chagasic dogs an increase of adipose tissue was observed. The interference of this fatty infiltration in the chronic chagasic inflammatory process is worthy been studied in better detail since adipocytes are able to produce TNF, MIF and TGF, which are chemical mediators involved in phenomena such as leukocyte migration to the inflammatory focus and collagen deposition ${ }^{16}$. Adipose or fibroadipose replacement has also been described in arrhythmogenic right ventricular cardiomyopathy and it is possible that similar inflammatory phenomena are involved in the genesis of this process in arrhythmogenic and chagasic cardiomyopathy ${ }^{6,24}$. If it is true that left ventricular arrhythmogenic cardiomyopathy is caused by a long-term myocarditis (from childhood to adult life) that ends, sometimes, by sudden death, the histopathological condition observed in the right atrium of the chagasic dog is also similar to that observed the arrhythmogenic cardiomyopathy, although it occurs in a higher intensity, in relation to myocytolysis, fibrosis, replacement for adipose tissue and lymphocyte infiltrate.

\section{RESUMO}

\section{Análise quantitativa das lesões cardíacas na cardiomiopatia chagásica crônica canina}

As lesões observadas na cardiopatia chagásica crônica frequentemente produzem alterações eletrocardiográficas e afetam a função cardíaca. Através de uma análise morfométrica computadorizada nós quantificamos as áreas ocupadas por músculo cardíaco, tecido conjuntivo fibroso e tecido adiposo no átrio direito de cães experimentalmente infectados pelo Trypanosoma cruzi. Todos os cães infectados apresentaram miocardite crônica fibrosante com graus variáveis de redução de músculo cardíaco, fibrose e substituição por tecido adiposo. No miocárdio atrial dos cães infectados pelas cepas Be78 e Be62 foram observados 34 e $50 \%$ de músculo cardíaco, 28 e $32 \%$ de fibrose e, 38 e $18 \%$ de tecido adiposo, respectivamente. A fibrose observada era tanto difusa quanto focal e, principalmente intrafascicular interrompendo total ou parcialmente o percurso dos feixes musculares. Tais alterações histológicas provavelmente contribuiram para o surgimento dos distúrbios eletrocardiográficos verificados em 10 dos 11 cães estudados e que são comuns na cardiopatia chagásica crônica humana. De todos os achados microscópicos encontrados, a fibrose foi a mais importante por produzir rearranjos na fibras colágenas em relação aos miocardiócitos, modificando a fisionomia anatômica e o comportamento mecânico do miocárdio. Tais anormalidades estruturais podem contribuir para o surgimento à disfunção cardíaca, arritmias e à insuficiência cardíaca congestiva como verificado em dois cães analisados. A cepa Be78 produziu uma destruição de músculo cardíaco atrial estatisticamente superior à induzida pela cepa Be62.

\section{ACKNOWLEDGEMENTS}

This paper was supported by FAPEMIG, CNPq and PRPq/UFMG. We also acknowledge to Professor Adlane Vilas-Boas Ferreira by the review of this manuscript.

\section{REFERENCES}

1. ANDRADE, S.G.; GRIMAUD, J.A. \& STOCKER-GUERRET, S. - Sequential changes of the connective matrix components of the myocardium (fibronectin and laminin) and evolution of cardiac fibrosis in mice infected with Trypanosoma cruzi. Amer. J. trop. Med. Hyg., 40: 252-260, 1989.

2. ANDRADE, Z.A.; ANDRADE, S.G.; SADIGURSKY, M. \& CAMARA, E.J. - Pathology of complete atrioventricular block in chronic Chagas' myocarditis. Rev. Soc. bras. Med. trop., 21: 7-13, 1988.

3. ANSELMI, A.; PIFANO, F.; SUAREZ, A. et al. - Experimental Schizotrypanum cruzi myocarditis. Correlation between histopathologic and electrocardiographic findings in experimental Chagas' heart disease. Amer. Heart J., 70: 638-656, 1965.

4. ARAÚJO, F.M.G. - Avaliação da doença de Chagas crônica experimental em cães. Ouro Preto, 2001. (Dissertação de Mestrado - Instituto de Ciências Exatas e Biológicas da Universidade Federal de Ouro Preto).

5. BARRETTO, A.C.; MADY, C.; ARTEAGA-FERNANDEZ, E. et al. - Right ventricular endomyocardial biopsy in chronic Chagas' disease. Amer. Heart J., 111: 307-312, 1986.

6. BASSO, C.; THIENE, G.; CORRADO, D. et al. - Arrhytmogenic right ventricular cardiomyopathy: dysplasia, dystrophy, or myocarditis? Circulation, 94: 983-991, 1996.

7. BOGLIOLO, L. - As causas anatômicas da insuficiência cardíaca na cardiopatia (miocardite) chagásica crônica, estudadas comparativamente com as causas anatômicas da insuficiência cardíaca noutras cardiopatias. Parte II. Arq. bras. Cardiol., 29: 479-483, 1976.

8. BRENER, Z. - Therapeutic activity and criterion of cure on mice experimentally infected with Trypanosoma cruzi. Rev. Inst. Med. trop. S. Paulo, 4: 389-396, 1962.

9. CALIARI, M.V. - Princípios de morfometria digital. KS300 para iniciantes. Belo Horizonte, Ed. UFMG, 1997. p. 1-149.

10. CALIARI, M.V.; LANA, M.; CAJÁ, R.A.F. et al. - Immunohistochemical studies in acute and chronic canine chagasic cardiomyopathy. Virchows Arch., 441: 69-76, 2002 
11. CARNEIRO, C.M.; MARTINS-FILHO, O.A.; CORREA-OLIVEIRA, R. et al. Phenotypic profile of peripheral blood leukocytes and splenocytes during chronic Trypanosoma cruzi infection in dogs. Mem. Inst. Oswaldo Cruz, 95 (suppl. 2): 187-188, 2000.

12. CHAGAS, C. - Nova tripanozomiase humana. Estudos sobre a morfolojia e o ciclo evolutivo do Schizotrypanum cruzi n. gen., n. sp., ajente etiolojico de nova entidade mórbida do homem. Mem. Inst. Oswaldo Cruz, 1: 159-218, 1909.

13. CONTROL of Chagas' disease. Report of a WHO Expert Committee. Geneva, World Health Organization, 1991.

14. DIAS, E.; LARANJA, F.S. \& NÓBREGA, G. - Doença de Chagas. Mem. Inst. Oswaldo Cruz, 43: 495-581, 1945.

15. ELIZARI, M.V. \& CHIALE, P.A. - Cardiac arrhytmias in Chagas' heart disease. J. cardiovasc. Electrophysiol., 4: 596-608, 1993.

16. FRÜHBECK, G.; GÓMES-AMBROSI, J.; MURUZÁBAL, F.J. \& BURREL, M.A. The adipocyte: a model for integration of endocrine and metabolic signaling in energy metabolism regulation. Amer. J. Physiol. Endocrinol. Metab., 280: E827-E847, 2001.

17. GARZON, S.A.C.; LORGA, A.M. \& NICOLAU, J.C. - Eletrocardiograma na cardiopatia chagásica. Rev. Soc. Cardiol. (S. Paulo), 4: 133-143, 1994.

18. LANA, M. \& CHIARI, C.A. - Caracterização biológica comparativa das cepas Berenice62 e Berenice-78 de Trypanosoma cruzi, isoladas da mesma paciente em diferentes períodos. Mem. Inst. Oswaldo Cruz, 81: 247-253, 1986.

19. LANA, M.; CHIARI, E. \& TAFURI, W.L. - Experimental Chagas' disease in dogs. Mem. Inst. Oswaldo Cruz, 87: 59-71, 1992.

20. LANA, M.; TAFURI, W.L.; CALIARI, M.V. et al. - Fase crônica cardíaca fibrosante da tripanosomíase cruzi experimental no cão. Rev. Soc. bras. Med. trop., 21: 113-121, 1988.

21. MACEDO, V. - Inquérito eletrocardiográfico nacional para doença de Chagas. Rev. Soc. bras. Med. trop., 26(suppl. 2): 12-13, 1993.

22. MADY, C.; IANNI, B.M.; ARTEAGA, E. et al. - Relation between interstitial myocardial collagen and the degree of clinical impairment in Chagas' disease. Amer. J. Cardiol., 84: $354-356,1999$.

23. ROSSI, M.A. - The pattern of myocardial fibrosis in chronic Chagas' heart disease. Int. J. Cardiol., 30: 335-340, 1991.
24. ROSSI, M.A. - Comparison of Chagas' heart disease to arrhythmogenic right ventricular cardiomyopathy. Amer. Heart J., 129: 626-629, 1995.

25. ROSSI, M.A. - Fibrosis and inflammatory cells in human chronic chagasic myocarditis: scanning electron microscopy and immunohistochemical observations. Int. J. Cardiol., 66: 183-194, 1998.

26. ROSSI, M.A. - Pathologic fibrosis and connective tissue matrix in left ventricular hypertrophy due to chronic arterial hypertension in humans. J. Hypertens., 16: 10311041,1998 .

27. SPACH, M.S. \& DOLBER, P.C. - Relating extracellular potentials and their derivatives to anisotropic propagation at a microscopic level in human cardiac muscle. Evidence for electrical uncoupling side-to-side fiber connections with increasing age. Circ. Res., 58: 356-371, 1986.

28. TAFURI, W.L. - Patogenia da doença de Chagas. Rev. Inst. Med. trop. S. Paulo, 29: 194-199, 1987.

29. TAFURI, W.L. - Immunopathology of Chagas disease: a historical overview. Mem. Inst. Oswaldo Cruz, 94(suppl. 1): 247-248, 1999.

30. TAFURI, W.L.; LANA, M.; CHIARI, E. et al. - O cão como modelo experimental para o estudo da história natural da doença de Chagas. Rev. Soc. bras. Med. trop., 21: $77,1988$.

31. TEIXEIRA, A.R.; CUNHA NETO, E.; RIZZO, L.V. \& SILVA, R. - Trypanocidal nitroarene treatment of experimental Trypanosoma cruzi infection does not prevent progression of chronic-phase heart lesions in rabbits. J. infect. Dis., 162: 1420, 1990.

32. WEBER, K.T. - Cardiac interstitium in health and disease: the fibrillar collagen network. J. Amer. Coll. Cardiol., 13: 1637-1652, 1989.

33. WEBER, K.T. \& BRILLA, C.G. - Pathological hypertrophy and cardiac interstitium. Fibrosis and renin-angiotensin-aldosterone system. Circulation, 83: 1849-1865, 1991.

34. WEBER, K.T.; SUN, Y.; TYAGI, S.G. \& CLEUTJENS, J.P. - Collagen network of the myocardium: function, structural remodeling and regulatory mechanisms. J. molec. Cell. Cardiol., 26: 279-292, 1994.

Received: 19 November 2001

Accepted: 18 July 2002 